\title{
Financial Integration and EMU
}

\author{
Franklin Allen
}

Department of Finance, The Wharton School of the University of Pennsylvania, 3620 Locust Walk, Philadelphia, PA 19104-636, USA

email: allenf@wharton.upenn.edu

\section{Wei-Ling Song}

Department of Finance, Bennett S. LeBow College of Business, Drexel University, 3141

Chestnut Street, Philadelphia, PA 19104, USA

email:wlsong@drexel.edu

\begin{abstract}
This paper investigates the effect of European Monetary Union on the integration of the financial services industry within European using data on the announcements of M\&A's within the industry. We find some evidence that EMU has helped financial integration within the euro area. In addition, financial institutions in EMU countries became more active in initiating integration between EMU and non-EMU partners, which also contributed to overall regional integration within European. The more active role of EMU institutions suggests that institutions residing in the eurozone became stronger players in the corporate control market. However, EMU does not facilitate the entry of non-European institutions into European.
\end{abstract}

Keywords: financial integration; financial institutions; mergers; euro.

JEL classification: $G 21, G 34, F 23$

\section{Introduction}

One of the major goals of the European Union is to create a single market for financial services. Since the financial system is crucial for the allocation of resources in the economy, a single market for financial services has the potential to significantly improve the efficiency of investment and increase growth. An important aspect of the move to create a single market is the role of EMU. One view is that having a single currency is important for having a single market. At the other extreme, some would argue that EMU is irrelevant. The purpose of this paper is to investigate this issue and consider the effect of EMU on the integration of the financial services industry.

Disentangling the effect of EMU from the many other factors that are relevant for financial integration is complex. Financial integration is occurring throughout the

The authors thank John Doukas for helpful suggestions. The corresponding author is Franklin Allen. 
world as part of the trend towards globalisation. An increased level of cross-border M\&A activities in recent years, both regional and global, is evident. In order to isolate the underlying movement of global financial integration from the regional one and gauge the effect of EMU in Europe, we examine the extent of integration in relative terms. We therefore compare integration in Europe with integration within two other regions. The first is North and South America (the Americas) and the second is Asia.

Our analysis of financial integration is based on the numbers of announcements of M\&A's in the financial services industry within the different areas. We divide these M\&A's into domestic, regional and global mergers. Although this is not an ideal measure of the degree of financial integration we believe it does provide useful insights.

The analysis shows that EMU played a significant role in financial integration within Europe. At the global level, compared to both the Americas and Asia, Europe increased in regional integration. Asia had more global integration, while there was no significant change in either regional or global integration in the Americas. In relative terms, EMU enhanced within Europe regional integration, but it did not facilitate the entry of non-European institutions into the European financial industry.

At the regional level, among the cross-border within Europe M\&A announcements, the shares of within EMU M\&As (both targets and acquirers are EMU members) declined prior to the introduction of the euro, but stopped declining at the EMU event. On the other hand, the shares of within non-EMU M\&As (both targets and acquirers are non-EMU members) remained constant during all stages of EMU. It appears that EMU had little effect on non-EMU European integration, but reversed the trend of declining integration within the eurozone. Besides, financial institutions from EMU states tend to be acquirers rather than targets in the cross-EMU M\&As (between EMU and non-EMU countries) following the introduction of euro. The more active role of EMU institutions in the corporate control market suggests that EMU put these institutions in a stronger position in the market than those in nonEMU countries. This result is of particular importance to the UK where the financial services industry is so important. It suggests that remaining outside the euro area may put UK institutions in a disadvantageous position. ${ }^{1}$

With regard to the question if EMU favours one type of financial services versus another, the results indicate that there were more M\&A activities among commercial banking and investment banking firms than insurance companies within the eurozone. It suggests that currency integration facilitates capital market integration, thus investment banking integration.

Taking all the findings together, our study shows that there is some evidence that EMU has helped financial integration within the euro area. In addition, financial institutions in EMU countries became more active in initiating cross-EMU integration, which also contributed to overall regional integration within Europe.

The paper is organised as follows. Section 2 discusses the developments in financial integration and currency unions. Section 3 describes the data. Section 4 presents the

\footnotetext{
${ }^{1}$ The recent acquisition of Abbey National (a UK bank) by Banco Santander (a Spanish bank) is consistent with this empirical observation. The deal will create the world's tenth largest bank by market value. See press release by Abbey National, 'Recommended acquisition by Banco Santander of Abbey National plc,' July 26, 2004, which is available at the following web site: http://www.abbeynational.com/home.htm.
} 
M\&A announcements of financial institutions around the world and the evidence on the impact of EMU on financial integration. Section 5 concludes.

\section{Financial integration and currency unions}

The move towards financial integration globally and regionally started long before the establishment of EMU. For example, Nolle (1995) reports that foreign banks' market share in the US commercial and industrial loan market increased from 19 to $47 \%$ between 1983 and 1993. Despite the low profits of foreign banks during the period from 1985 to 1990, the market share of foreign banks surged (DeYoung and Nolle, 1996). ${ }^{2}$ Grosse and Goldberg (1991) show that foreign banks entered the US market to serve the international trade and direct investment needs of their home-country clients. Economic forces appeared to facilitate the entry of foreign financial institutions into the USA without any formal coordination among countries. During this time period, on the other hand, European countries actively engaged in formal coordination to integrate the market. Cross-border M\&As of financial institutions within Europe also increased during the 1990s (Berger et al., 1999).

The effort to integrate the European community is not a recent phenomenon. It started as early as 1957 according to the history of the euro provided by the European Central Bank: ${ }^{3}$

The Treaty of Rome (1957) declared a common European market as a European objective with the aim of increasing economic prosperity and contributing to an ever closer union among the peoples of Europe.

The Single European Act (1986) and the Treaty on European Union (1992) have built on this, introducing Economic and Monetary Union (EMU) and laying the foundations for our single currency.

The third stage of EMU began on 1 January 1999, when the exchange rates of the participating currencies were irrevocably set. Euro area Member States began implementing a common monetary policy, the euro was introduced as a legal currency and the 11 currencies of the participating Member States became subdivisions of the euro. Greece joined on 1 January 2001 and so 12 Member States introduced the new euro banknotes and coins at the beginning of this year [2002].

Given the increased trend of globalisation, further integration of different markets seems likely to occur. However, the question is if a formal coordination effort, such as EMU, facilitates integration more than if such an effort had never been implemented. Since we cannot observe what would have happened in Europe without such a coordinated effort and there is no other region that resembles Europe closely enough to act as a perfect benchmark, this is a challenging question to answer.

The effect of currency unions has been examined by Rose and Engel (2002). They found that members of international currency unions tend to have more trade, less volatile exchange rates, and more synchronised business cycles than do countries with their own currencies. However, such integration is far less than that of the intranational benchmark of regions within a country. As pointed out by these authors, countries that are already well-integrated

\footnotetext{
${ }^{2}$ DeLong (2001), using US bank mergers, shows that focusing bank mergers create more shareholder wealth than diversifying bank mergers.

${ }^{3}$ The information on the history of euro is posted on the web site of the European Central Bank (http://www.euro.ecb.int/en/what/history.html).
} 
may be more likely to adopt a common currency. Therefore, some of the integration results may be illusive. Besides, since the currency unions in their sample tend to be small or poor countries, their findings may not be reliably extrapolated when it comes to EMU.

In this paper, we attempt to address the above question by using the announcements of M\&As by financial institutions around the world. The announcement indicates the intention of a financial institution to integrate its business with another institution completely or partially. When such a deal involves a cross-border transaction, it is not only a form of foreign direct investment but also a way of increasing economic integration across countries (di Giovanni, 2004). Although there is an extensive literature on banking mergers (see, for example, Berger etal., 2000), few have formally examined the impact of EMU on financial industry consolidation within Europe and tried to contrast the extent of financial institution M\&As around the world. ${ }^{4}$ None, to the best of our knowledge, has used the recent M\&A data up to May 2003.

\section{Data and sample selection}

The announcements of M\&A transactions between financial institutions are obtained from the Worldwide Mergers and Acquisitions database of SDC Platinum. We ignore the countries with less than $50 \mathrm{M} \& \mathrm{~A}$ deals during our sample period, which is from 1 June 1988 to 31 May 2003. If the first digit of the Standard Industry Classification Code (SIC code) of either target or acquirer is 6 , the deal is included in the sample. We only consider the transactions conducted by corporations. Therefore, we exclude the deals involving private investors or investing groups. In terms of transaction type, we exclude acquisitions of remaining interests (1,854 deals), exchange offers (46 deals), and recapitalisation (24 deals).

The list of transaction types included in this study is reported in Table 1. Among the 47,228 deals, 45,609 are initiated by acquirers with the first digit SIC code of 6 . As to targets, there are 45,156 deals having the first digit SIC code of 6. Mergers account for 11,072 deals. There are 4,833 $(10,018)$ acquisitions of major (partial) interest. Acquisitions of assets account for 20,797 transactions. We focus on the frequency of worldwide M\&A activities because there is too much missing information for the value of transactions. In contrast to most of the empirical M\&A studies, which require extensive financial information on both acquirers and targets and inevitably eliminate many observations, our analysis on the frequency of deals permits a more comprehensive investigation of M\&A activities.

The inclusion of broader definitions of M\&As also captures most of the intention to integrate businesses of different nationalities. However, the large number of observations means it is not possible to hand check all the cross-border deals and rule out transactions involving domestic purchasing of foreign owned assets. For example, a US financial institution may purchase the US subsidiary of a German bank. Such a transaction will be counted as a cross-border deal in our study. Similar classification problems exist in other types of cross-border studies. Eichengreen and Park (2003) point out that the BIS (Bank for International Settlements) consolidated claims, which also

\footnotetext{
${ }^{4}$ Goergen and Renneboog (2004) study the European domestic and cross-border takeover bids by using data from 1993 to 2000. They find that the stock price announcement effects are significantly higher if a UK firm is involved than those of bids involving both a regional European target and bidder. Beitel et al. (2004) study European banking M\&As from 1985 to 2000. The geographical focus in their study is classified by domestic or cross-border rather than EMU membership. See also Cybo-Ottone and Murgia (2000) for European banking M\&As during earlier years.
} 
Table 1

M\&As of financial institutions by acquisition type.

This table reports the frequency of both domestic and cross-border M\&A activities of financial institutions by merger type during three stages of EMU development. Stage 1 is from 1 June 1988 to 31 May 1993. Stage 2 is from 1 June 1993 to 31 May 1998. Stage 3 is from 1 June 1998 to 31 May 2003.

\begin{tabular}{lrrrr}
\hline M\&A type & Stage 1 & Stage 2 & Stage 3 & All \\
\hline Merger & 2,264 & 4,249 & 4,559 & 11,072 \\
Acquisition of major interest & 980 & 1,843 & 2,010 & 4,833 \\
Acquisition of partial interest & 2,574 & 3,687 & 3,757 & 10,018 \\
Acquisition of assets & 4,955 & 7,176 & 8,666 & 20,797 \\
Acquisition of certain assets & 100 & 66 & 106 & 272 \\
Acquisition & 59 & 83 & 94 & 236 \\
Total & 10,932 & 17,104 & 19,192 & 47,228 \\
\hline
\end{tabular}

provide a broad measure of financial integration, distinguish banks by nationality. It sums global contractual lending by the head office and its branches and subsidiaries on a consolidated basis. Therefore, claims of UK bank branches operating in the USA and raising funds in the USA in order to extend loans to US borrowers are counted as UK claims on the USA. Therefore, our analysis of M\&As between two parent holding companies of different nationalities captures financial integration in a broad sense.

EMU started with the elimination of capital controls and intensified coordination among central banks in 1990. However, not until 1 June 1998, was the European Central Bank officially created (Micco et al., 2003). We use 1 June 1998 as the date to mark the beginning of the EMU era and study worldwide M\&A activities for 5 years following this date. Because it usually takes several months or years for mergers to become effective and we use M\&A announcement dates to classify the sample period, we would argue that 1 June 1998, is, in fact, a better date to use than 1 January 1999 as the start of EMU. We extend the analysis 10 years prior to 1 June 1998 to contrast the worldwide M\&A activities surrounding the EMU event date. Formally, we analyse three stages of EMU development. Stage 1 is from 1 June 1988 to 31 May 1993, which is the initial stage of EMU. Stage 2 is from 1 June 1993 to 31 May 1998, which is the active planning stage of EMU. Stage 3 is from 1 June 1998 to 31 May 2003, which is the formal establishment of EMU.

\section{Worldwide M\&As of Financial Institutions}

Cross-border mergers and acquisitions surged to an unprecedented level in 2000. In 1990, based on constant 1987 US dollars, the total value of such transactions amounted to $\$ 135$ billion. This increased to $\$ 828$ billion in 2000 , which is equivalent to $\$ 1.1$ trillion in 2000 dollars (Evenett, 2003). In this section, we use the number of announced financial institution M\&As to infer cross-border financial integration of a region based on a target region or a target country. More focused analysis is also conducted within Europe, in particular with the emphasis on comparing EMU versus non-EMU countries.

\subsection{Financial institution $M \& A$ s based on target region}

Table 2 reports financial institution M\&As by regional scope based on target regions. Panel A shows that North and South America accounted for $50.54 \%$ of all deals; 
followed by Europe (34.16\%), then by Asia (15.3\%). Although the North and South America region (mainly the USA and Canada) constituted more than half of the deals over the three stages of EMU, its share of all deals was declining, while Asia increased its share. Europe declined then increased in the percentage of all deals. Comparing Panels A and B, it is obvious that the trends in Panel A (all deals) are driven by the trends in Panel B (domestic deals).

Panel $\mathrm{C}$ reports the cross-border within region M\&A activities. Therefore, the target and the acquirer are from different countries but reside in the same region, which

Table 2

M\&As of financial institutions by regional scope.

This table reports the frequency and percentage distribution of both domestic and cross-border M\&A activities of financial institutions by target region during three stages of EMU development. Stage 1 is from 1 June 1988 to 31 May 1993. Stage 2 is from 1 June 1993 to 31 May 1998. Stage 3 is from 1 June 1998 to 31 May 2003. Difference in percentage across consecutive periods is tested by a z-test.

\begin{tabular}{|c|c|c|c|c|c|c|c|c|}
\hline \multirow[b]{2}{*}{ Stage } & \multicolumn{4}{|c|}{ Frequency } & \multicolumn{4}{|c|}{ Percentage } \\
\hline & Europe & Americas & Asia & All & Europe & Americas & Asia & All \\
\hline \multicolumn{9}{|c|}{ Panel A: All $M \& A$} \\
\hline Total & 16,135 & 23,867 & 7,226 & 47,228 & 34.16 & 50.54 & 15.3 & 100 \\
\hline 1 & 4,126 & 6,161 & 645 & 10,932 & 37.74 & 56.36 & 5.9 & 100 \\
\hline 2 & 5,481 & 9,434 & 2,189 & 17,104 & 32.05 & 55.16 & 12.8 & 100 \\
\hline 3 & 6,528 & 8,272 & 4,392 & 19,192 & 34.01 & 43.1 & 22.88 & 100 \\
\hline z-test (2-1) & & & & & $-9.8 * * *$ & $-1.97 * *$ & $18.69 * * *$ & \\
\hline z-test (3-2) & & & & & $3.98 * * *$ & $-22.94 * * *$ & $9.19 * * *$ & \\
\hline \multicolumn{9}{|c|}{ Panel B: Domestic $M \& A$} \\
\hline Total & 10,603 & 20,918 & 5,156 & 36,677 & 28.91 & 57.03 & 14.06 & 100 \\
\hline 1 & 2,860 & 5,471 & 414 & 8,745 & 32.7 & 62.56 & 4.73 & 100 \\
\hline 2 & 3,693 & 8,494 & 1,499 & 13,686 & 26.98 & 62.06 & 10.95 & 100 \\
\hline 3 & 4,050 & 6,953 & 3,243 & 14,246 & 28.43 & 48.81 & 22.76 & 100 \\
\hline z-test $(2-1)$ & & & & & $-9.19 * * *$ & -0.75 & $16.26 * * *$ & \\
\hline z-test (3-2) & & & & & $2.7 * * *$ & $-22.28 * * *$ & $26.29 * * *$ & \\
\hline \multicolumn{9}{|c|}{ Panel C: Cross-border $M \& A$ within region } \\
\hline Total & 3,379 & 955 & 981 & 5,315 & 63.57 & 17.97 & 18.46 & 100 \\
\hline 1 & 792 & 127 & 134 & 1,053 & 75.21 & 12.06 & 12.73 & 100 \\
\hline 2 & 1,066 & 362 & 398 & 1,826 & 58.38 & 19.82 & 21.8 & 100 \\
\hline 3 & 1,521 & 466 & 449 & 2,436 & 62.44 & 19.13 & 18.43 & 100 \\
\hline z-test $(2-1)$ & & & & & $-9.09 * * *$ & $5.34 * * *$ & $6.04 * * *$ & \\
\hline z-test (3-2) & & & & & $2.69 * * *$ & -0.57 & $-2.72 * *$ & \\
\hline \multicolumn{9}{|c|}{ Panel D: Cross-region $M \& A$} \\
\hline Total & 2,153 & 1,994 & 1,089 & 5,236 & 41.12 & 38.08 & 20.8 & 100 \\
\hline 1 & 474 & 563 & 97 & 1,134 & 41.8 & 49.65 & 8.55 & 100 \\
\hline 2 & 722 & 578 & 292 & 1,592 & 45.35 & 36.31 & 18.34 & 100 \\
\hline 3 & 957 & 853 & 700 & 2,510 & 38.13 & 33.98 & 27.89 & 100 \\
\hline z-test $(2-1)$ & & & & & $1.84^{*}$ & $-6.96^{* * *}$ & $7.20 * * *$ & \\
\hline z-test (3-2) & & & & & $-4.59 * * *$ & -1.52 & $6.96 * * *$ & \\
\hline
\end{tabular}

***,**, ${ }^{*}$ Significant at $1 \%, 5 \%$, or $10 \%$ level, respectively, for a two-tailed test. 
indicates the degree of regional integration. We label this kind of M\&A transaction as a regional deal. The percentage for Europe is calculated by the number of regional deals in Europe divided by the total number of similar deals (same stage and same regional focus) in all three regions. The high percentages of European regional M\&As show that European countries have been actively engaging in regional integration throughout the period. The highest percentage $(75.21 \%)$ occurred at stage 1 of EMU development. It then dropped about $16.8 \%$ to $58.38 \%$ during stage 2 , but reversed the trend and increased to $62.44 \%$ during stage 3 . Although, in terms of raw numbers, all regions increased in regional M\&As, Europe is the only region that shows an increase in relative terms from stage 2 to stage 3. During the same period, both North and South America and Asia decline in percentage terms, and the decline is statistically significant for Asia. These numbers indicate that, surrounding the establishment of EMU, there is more regional integration within Europe than that within other regions.

Cross-region deals are reported in Panel D, which we label as global transactions. Again, in terms of raw numbers, all regions increase in global M\&As. The trend of globalisation is evident. Among the three regions, Europe appears to have the highest percentage of global deals on average. However, during the latter period, its shares of global deals dropped from $45.35 \%$ to $38.13 \%$. North and South America's share of global deals declined over the three periods, but Asia increased dramatically. It appears that, although EMU facilitates within Europe financial integration, it does not facilitate the entry of non-European countries' financial institutions into Europe.

Figure 1 graphs the percentages in Panels B, C and D of Table 2. It is clear that North and South America is the major player of domestic M\&As, but Asia is gaining share over time in this category. Europe dominates the regional M\&As. Both Europe and North and South America lost ground to Asia in global M\&As.

While Figure 1 slices each type of M\&A by region, Figure 2 slices the total deals of each region by type of $M \& A$. Therefore, the share (relative importance) of each type of M\&A for each region is standardised by the region's own capacity to have M\&A activities. Because the number of M\&A deals increases for most of the regions during the sample period, in particular, the later EMU stages. If the share of regional M\&As increases in a region (or in a country) over time, then it indicates not only an increase in absolute number but also an increase in relative importance among different deal types. Because the comparison is within a region (or country) over time, we could

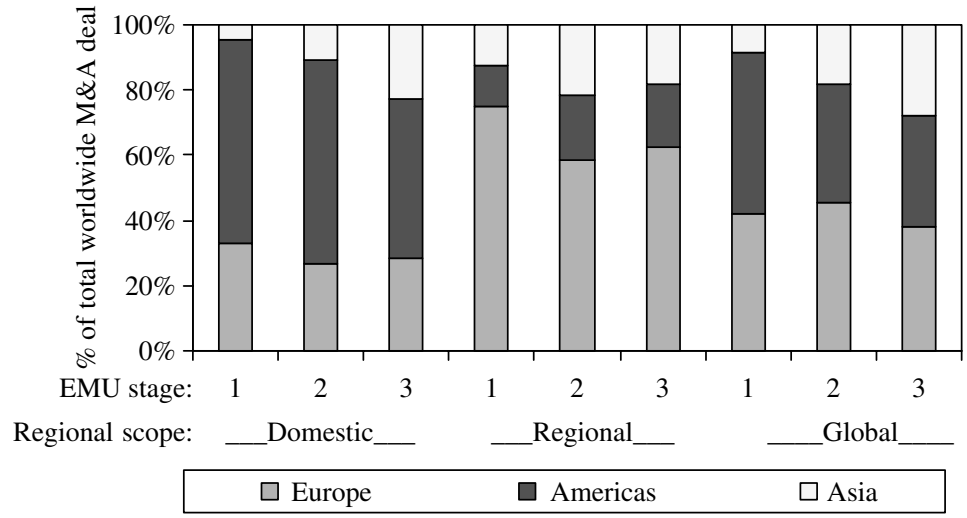

Fig. 1. Distribution of financial institution M\&As by regional scope based on target continents as a percentage of total M\&A deals 


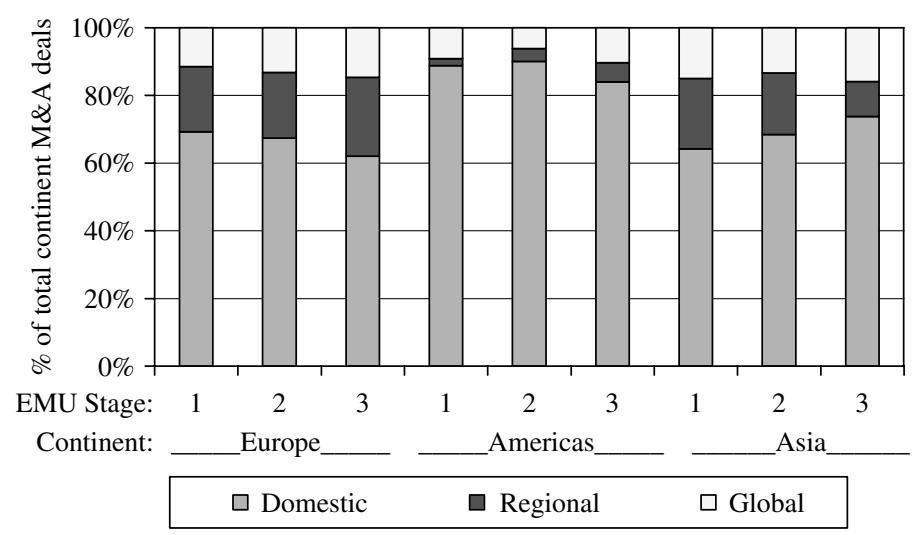

Fig. 2. Distribution of financial institution M\&As by target continent based on regional scope as a percentage of total M\&A deals

'Domestic' indicates within country M\&A activities. 'Regional' indicates cross-border within region M\&A activities. 'Global' indicates cross-region M\&A activities. Stage 1 is from 1 June 1988 to 31 May 1993. Stage 2 is from 1 June 1993 to 31 May 1998. Stage 3 is from 1 June 1998 to 31 May 2003.

infer from such an empirical observation that there is more regional integration among financial institutions within a region (or country).

Figure 2 shows that both regional and global M\&As increased their share and squeezed out domestic activities in Europe. The same trend occurred in North and South America from stage 2 to 3. Asia appears to increase in both global and domestic deals but decline in regional deals in percentage terms. Although globalisation occurs in all regions, Asia is behind in regional integration in relative terms. In contrast to Asia, Europe is not only traditionally active in regional integration but continues to be so more than other regions regardless of the measure used.

\subsection{Financial institution $M \& A s$ based on target country}

Although, in aggregate, Europe appears to increase in M\&A activity over time, the trends are very heterogeneous among European countries. About half show an increased trend of all types of M\&A deals during the three stages of EMU developments as reported in Panel A of Table 3. Among the countries that did not always demonstrate an increased trend, six are counted as EMU countries while three do not have EMU membership. ${ }^{5}$ However, as to cross-border deals, the increase in trend occurs for all countries except for Finland and Russia. As Panels B and C of Table 3 have shown, most of the North and South American and Asian countries have increased total M\&As over time. ${ }^{6}$ The only exceptions are the USA, Venezuela, and Indonesia. However, in terms

\footnotetext{
${ }^{5}$ There are 12 countries with EMU memberships listed in Table 3. However, we count Denmark as an EMU country because its exchange rate is pegged to the euro. Excluding Denmark in the group does not change the conclusions of the paper.

${ }^{6}$ In Table 3, we report the information on China and Hong Kong separately because the economic developments are very different between these two regions. The M\&A deals between China and Hong Kong are counted as cross-border deals in Table 3. However, in Figure 6, we count such deals as domestic. There are 98 (104) deals where a Hong Kong (China) entity is an acquirer and a China (Hong Kong) institution is the target.
} 


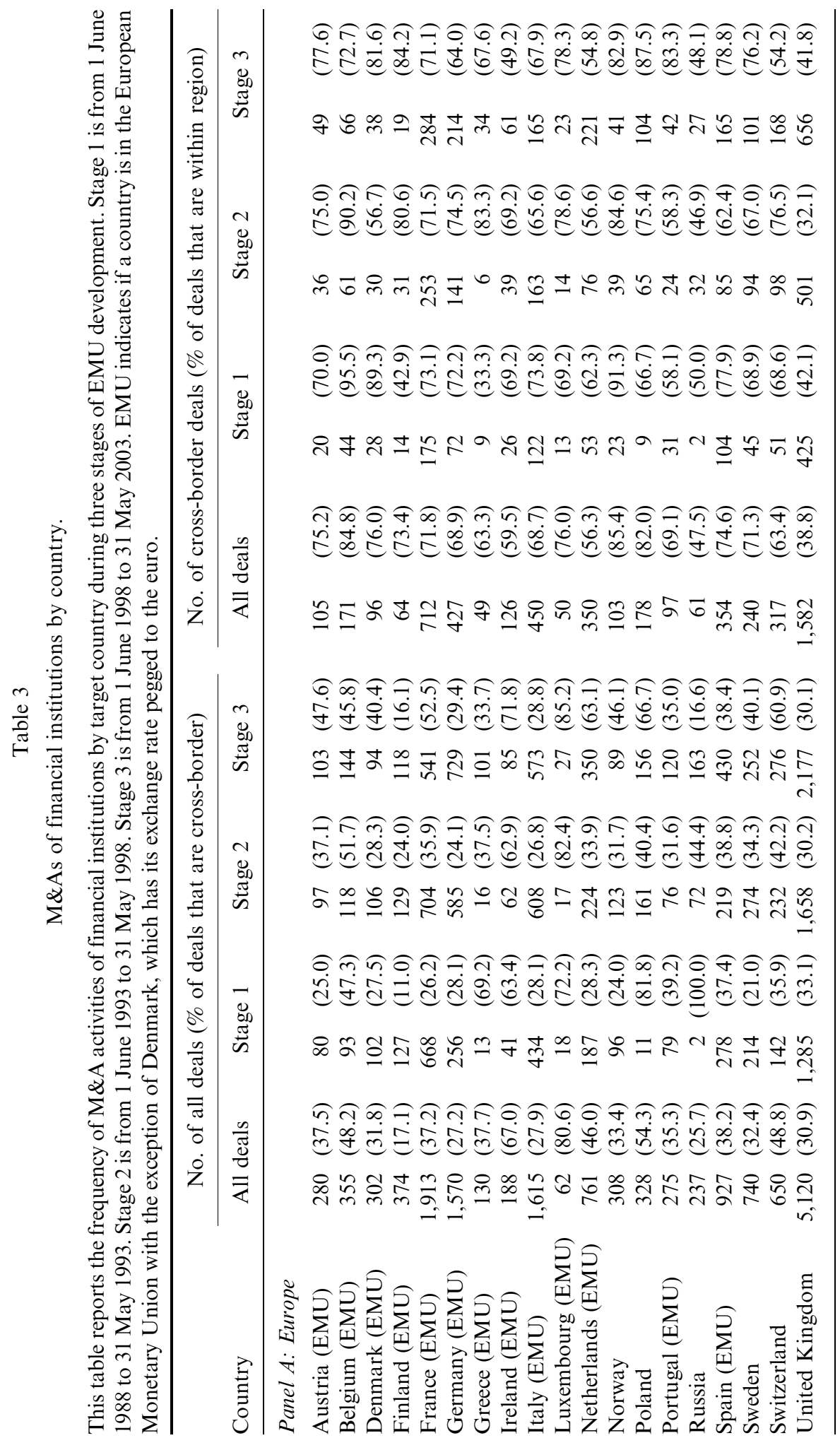




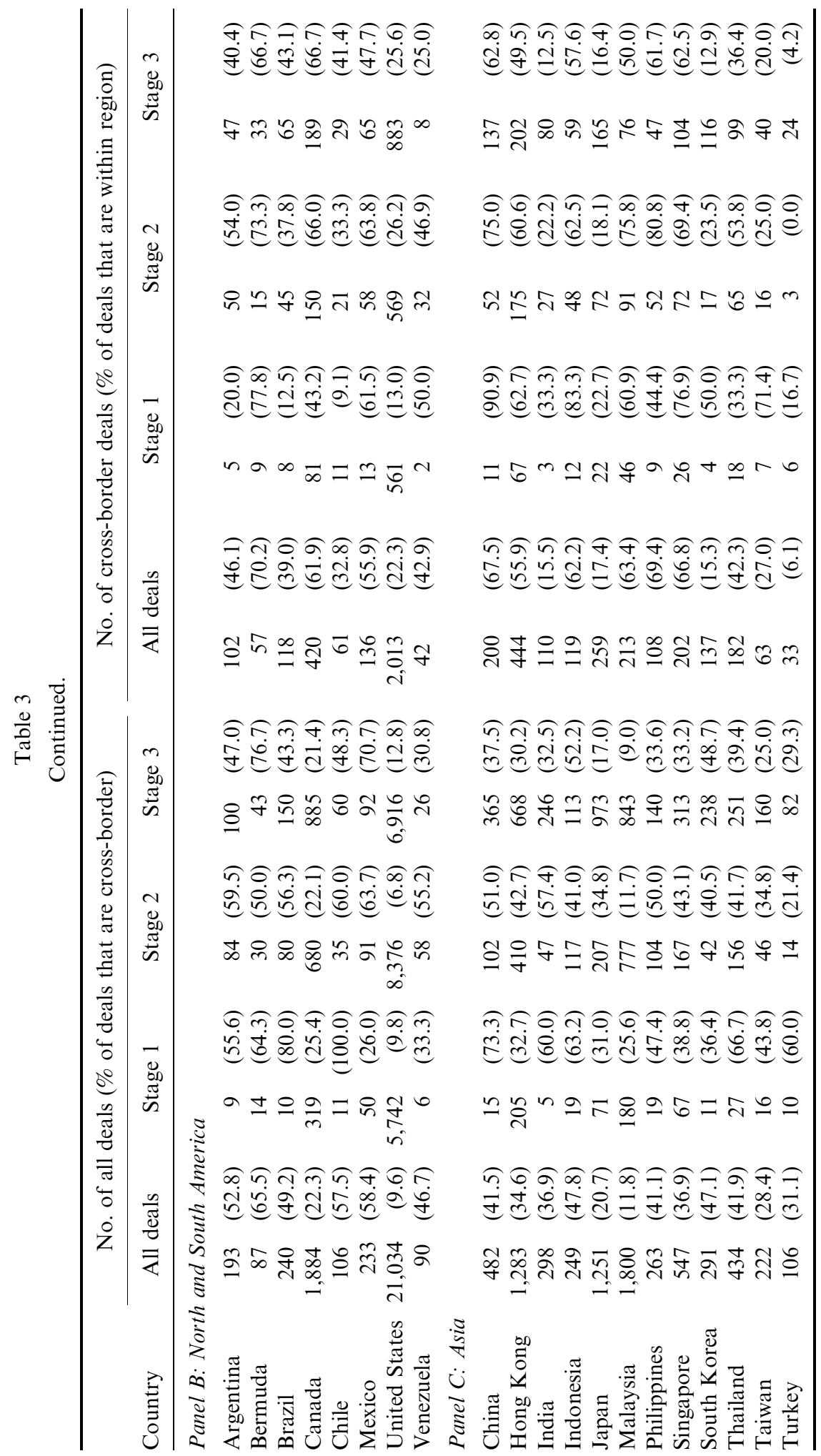


of cross-border deals, Argentina, Venezuela, Malaysia, and the Philippines are the only countries that decline in M\&A transactions during the latter EMU stages.

4.2.1. Financial institution $M \& A s$ by $G 7$ country. Figure 3 compares three EMU-G7 countries (France, Germany and Italy) to non-EMU-G7 countries (Canada, Japan, the UK, and the USA). Therefore, the level of economic development is controlled for in such a comparison. Again, EMU countries demonstrate higher shares of regional M\&As, but only France shows increasing regional integration. Among the non-EMU countries, in general, Japan and the UK have larger shares of global M\&As than other nations. The USA shows the largest share of domestic M\&As. Except for France, other G7 nations did not demonstrate a clear trend of increased cross-border M\&A deals during the three stages of EMU. Perhaps because we present the data based on target nations and these are developed countries, this indicates it is harder for institutions from other nations to enter in the later periods.

4.2.2. Financial institution $M \& A s$ by non-G7 European country. Figure 4 shows that, among the 10 non-G7 EMU countries, Belgium, Finland, and Greece do not increase in either regional or global M\&As from EMU stage 2 to stage 3. A closer look at Table 3 indicates that the number of cross-border deals for Belgium increased from 61 to 66 during the latter stages of EMU; that for Greece increased from 6 to 34. However, for Finland they dropped from 31 to 19. Therefore, surrounding the establishment of EMU, the majority of EMU countries do show some signs of further regional or global integration. Nonetheless, such integration is not unique for EMU countries. Figure 5 demonstrates the same pattern for non-EMU European countries with only one exception, Russia. The number of cross-border deals for Russia dropped from 32 to 27 in Table 3. These empirical observations seem to suggest that EMU facilitates

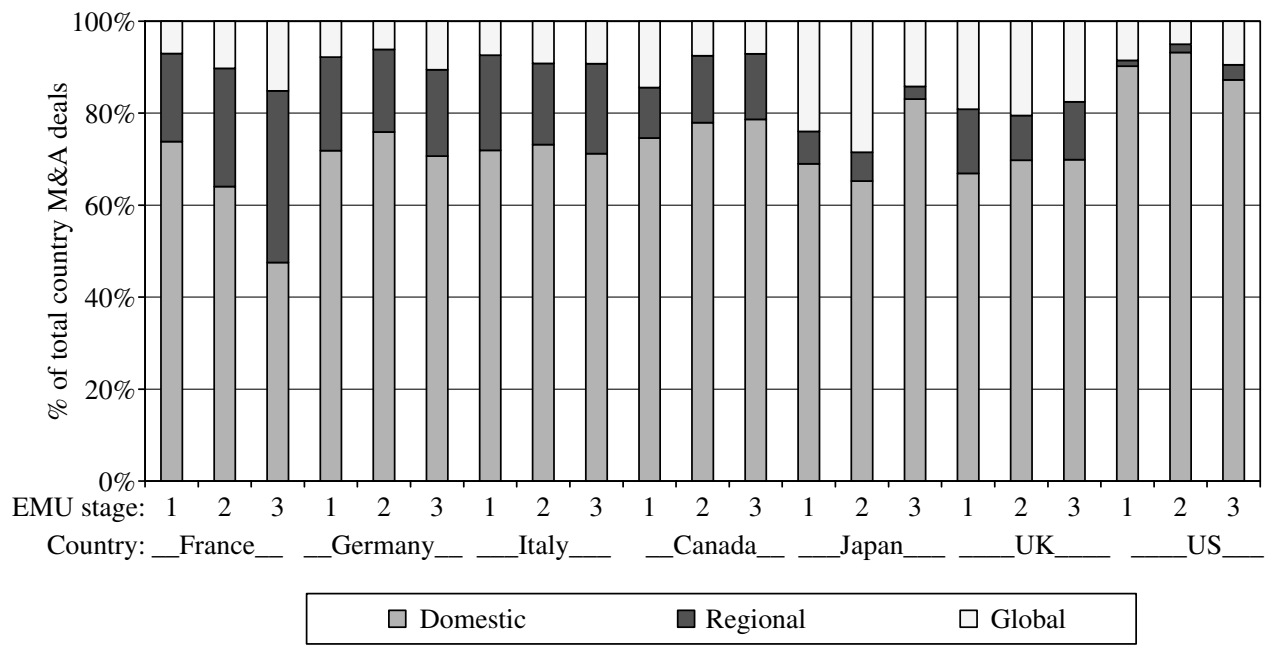

Fig. 3. M\&As of financial institutions by G7 country

'Domestic' indicates within country M\&A activities. 'Regional' indicates cross-border within region M\&A activities. 'Global' indicates cross-region M\&A activities. Stage 1 is from 1 June 1988 to 31 May 1993. Stage 2 is from 1 June 1993 to 31 May 1998. Stage 3 is from 1 June 1998 to 31 May 2003. 


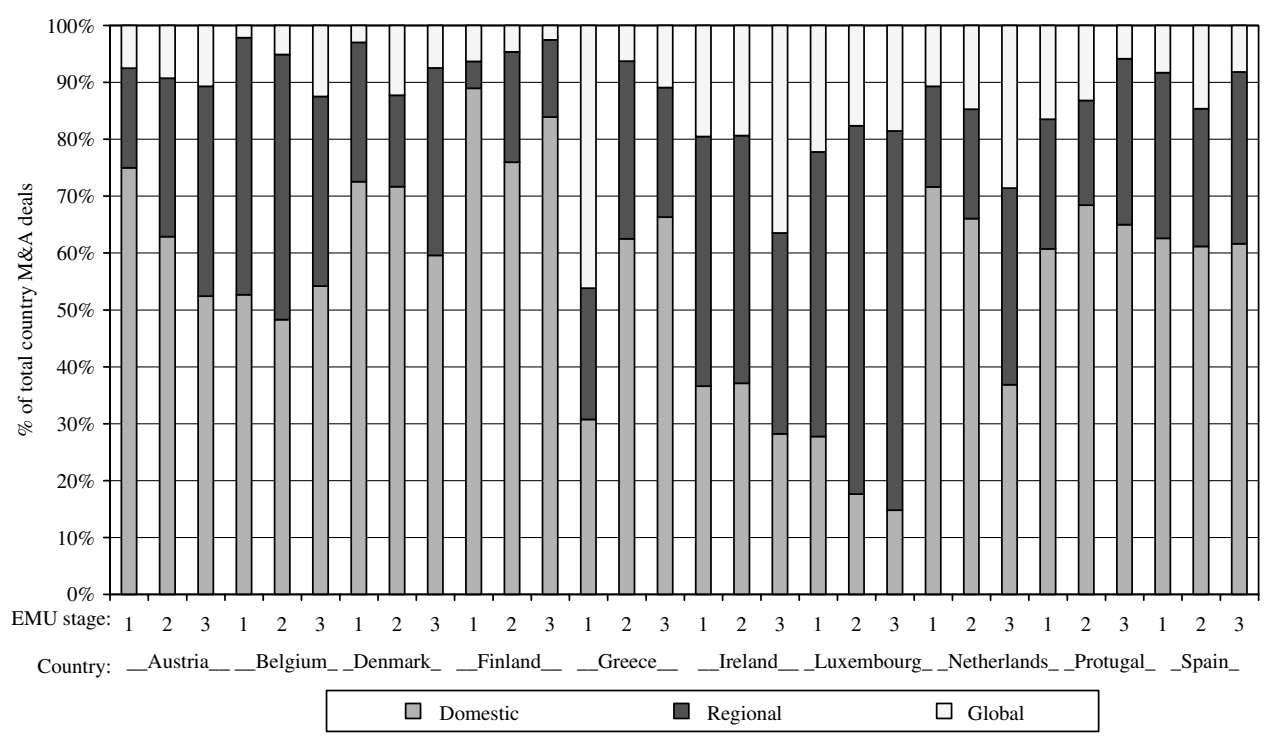

Fig. 4. M\&As of financial institutions by non-G7 EMU country

'Domestic' indicates within country M\&A activities. 'Regional' indicates cross-border within region M\&A activities. 'Global' indicates cross-region M\&A activities. Stage 1 is from 1 June 1988 to 31 May 1993. Stage 2 is from 1 June 1993 to 31 May 1998. Stage 3 is from 1 June 1998 to 31 May 2003.

financial integration not only for EMU countries but also for non-EMU European countries. However, one cannot rule out the possibility that such an increase in financial integration is just a part of more general globalisation. Therefore, we also examine the M\&As of Asian countries as a benchmark comparison. Although such a benchmark is not ideal, it is perhaps better than nothing.

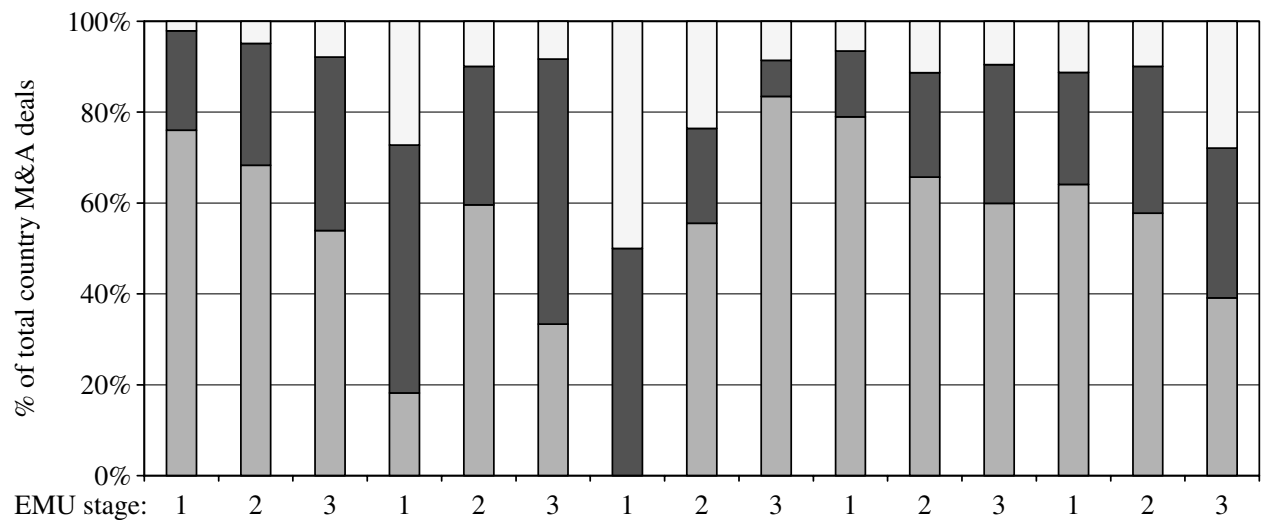

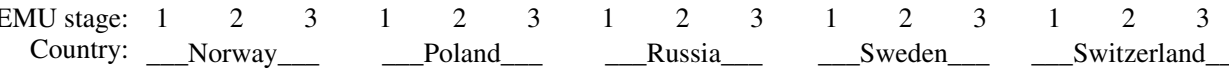

$\square$ Domestic $\quad \square$ Regional $\quad \square$ Global

Fig. 5. M\&As of financial institutions of non-EMU and non-G7 European country 'Domestic' indicates within country M\&A activities. 'Regional' indicates cross-border within region M\&A activities. 'Global' indicates cross-region M\&A activities. Stage 1 is from 1 June 1988 to 31 May 1993. Stage 2 is from 1 June 1993 to 31 May 1998. Stage 3 is from 1 June 1998 to 31 May 2003. 
4.2.3. Financial institution $M \& A s$ by Asian country. In contrast to European countries, the share of cross-border M\&As for most Asian countries did not increase surrounding the establishment of EMU (from stage 2 to stage 3). As Figure 6 shows, only Indonesia and South Korea increased their shares in cross-border M\&As. ${ }^{7}$ However, for South Korea this is mainly global integration rather than regional integration. Although the shares of cross-border deals declined in most Asian countries, as Table 3 indicates, this is mainly driven by the relatively larger increase in domestic M\&As. This development of relatively more domestic M\&As, is consistent with the fact that many Asian countries had to deal with large amounts of non-performing loans following the Asian Crisis. M\&A between banking institutions is a major way to resolve the problem of distressed bank assets.

Among the Asian crisis countries, both South Korea and Thailand have introduced various measures to encourage business consolidations through M\&As and to liberalise foreign investment (Mody and Negishi, 2001). Although not as dramatic as South Korea, which experienced a boom of nearly 5 times in the number of M\&As from EMU stage 2 to 3, Thailand increased from 156 to 251 as Table 3 reports. Combining the information in Figure 6 and Table 3 shows that the upsurge of M\&As is more pronounced in domestic and global M\&As rather than regional ones.

\subsection{Cross-border M\&As of financial institutions within Europe}

In this subsection, we take a closer look within Europe. Table 4 reports the cross-border M\&As of financial institutions among European countries by EMU membership. In all categories of EMU types, the numbers of regional M\&As surged over time. It is evident that regional integration continues to be very active among

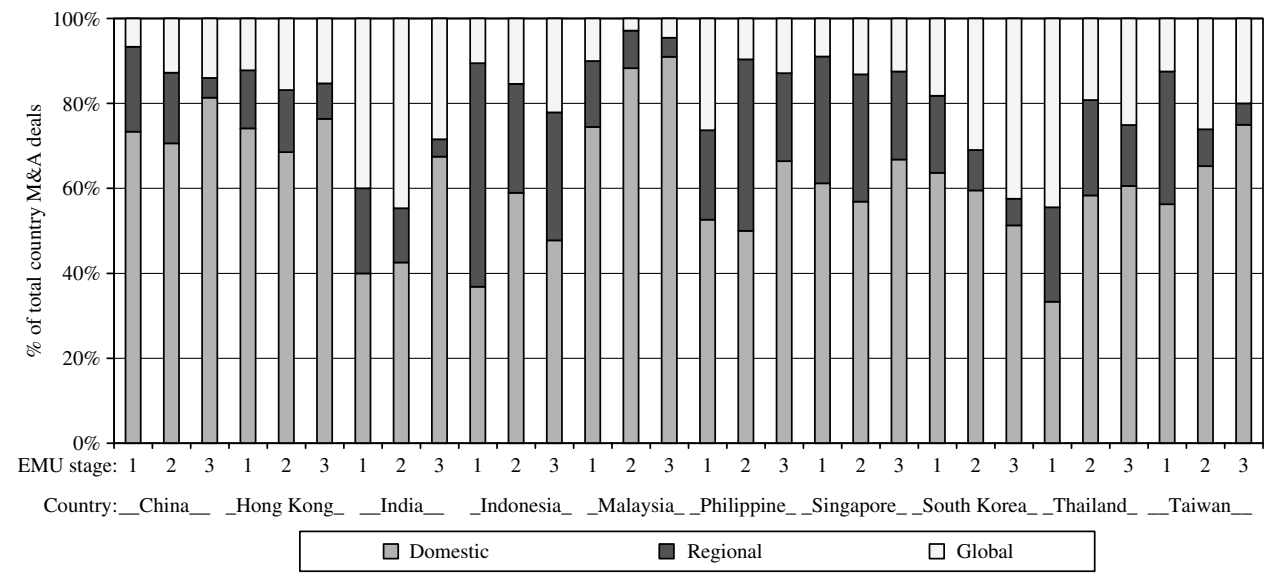

Fig. 6. M\&As of financial institutions by Asian country

'Domestic' indicates within country M\&A activities. 'Regional' indicates cross-border within region M\&A activities. 'Global' indicates cross-region M\&A activities. Stage 1 is from 1 June 1988 to 31 May 1993. Stage 2 is from 1 June 1993 to 31 May 1998. Stage 3 is from 1 June 1998 to 31 May 2003.

\footnotetext{
${ }^{7}$ We left out Turkey to keep the graph more concise and because it is the only non-East Asian country. 
Table 4

Cross-border M\&As of financial institutions within Europe.

This table reports the frequency and percentage of M\&A activities of financial institutions by target EMU status during three stages of EMU development. Stage 1 is from 1 June 1988 to 31 May 1993. Stage 2 is from 1 June 1993 to 31 May 1998. Stage 3 is from 1 June 1998 to 31 May 2003. Difference in percentage across consecutive periods is tested by a z-test.

\begin{tabular}{|c|c|c|c|c|c|}
\hline Stage & $\begin{array}{l}\text { EMU \& } \\
\text { EMU }\end{array}$ & $\begin{array}{c}\text { Target EMU \& } \\
\text { acquirer non-EMU }\end{array}$ & $\begin{array}{l}\text { Acquirer EMU \& } \\
\text { target non-EMU }\end{array}$ & $\begin{array}{c}\text { Non-EMU \& } \\
\text { non-EMU }\end{array}$ & All \\
\hline \multicolumn{6}{|c|}{ Panel A: Frequency } \\
\hline Total & 1,394 & 736 & 910 & 339 & 3,379 \\
\hline 1 & 356 & 163 & 197 & 76 & 792 \\
\hline 2 & 416 & 254 & 280 & 116 & 1,066 \\
\hline 3 & 622 & 319 & 433 & 147 & 1,521 \\
\hline \multicolumn{6}{|c|}{ Panel B: Percentage distribution } \\
\hline Total & 41.25 & 21.78 & 26.93 & 10.03 & 100 \\
\hline 1 & 44.95 & 20.58 & 24.87 & 9.6 & 100 \\
\hline 2 & 39.02 & 23.83 & 26.27 & 10.88 & 100 \\
\hline 3 & 40.89 & 20.97 & 28.47 & 9.66 & 100 \\
\hline z-test $(2-1)$ & $-2.56 * * *$ & $1.66^{*}$ & 0.68 & 0.9 & \\
\hline z-test $(3-2)$ & 0.96 & $-1.72 *$ & 1.23 & -1.01 & \\
\hline
\end{tabular}

$* * *, * *, *$ Significant at $1 \%, 5 \%$, or $10 \%$ level, respectively, for a two-tailed test.

European countries. However, the question is if the establishment of EMU favoured further integration among EMU members relative to non-EMU countries.

In relative terms, within EMU integration (EMU \& EMU) appears to decline significantly during stages 1 and 2 of EMU, then stop declining surrounding the establishment of EMU. Nonetheless, the opposite (an increase then a decline, but insignificantly) occurred for within non-EMU integration (non-EMU \& non-EMU). EMU seemed to have little effect on within non-EMU integration, but reversed the declining integration within the EMU group. These results are consistent with the claim that EMU facilitated financial integration among its member countries, although weakly.

As to the entries to EMU countries (targets) of non-EMU members (acquirers), the percentage increased then declined significantly. However, the entries to non-EMU countries of EMU members continued to increase during stages $1-3$. These numbers show that financial institutions in EMU countries are more active in initiating cross-EMU (between EMU and non-EMU countries) integration. The evidence implies that EMU put the institutions in EMU countries in a stronger position in the market than those in non-EMU countries. ${ }^{8}$ Therefore, EMU institutions tend to be acquirers rather than targets following the introduction of the euro. It further supports the argument that EMU had more impact on its members relative to other non-EMU European countries. However, the comparison with Asia seems to suggest

\footnotetext{
${ }^{8}$ The reduction in transaction costs, such as currency exchange costs and risk management, may make institutions residing in the eurozone more efficient on the cost dimension. Of course, firms outside the eurozone may also benefit from such a currency union, but probably to a less extent. See Christie and Marshall (2001) on the effect of the euro on UK multinational companies.
} 
that EMU benefits most of the European nations in regional integration but it facilitates EMU members more than non-EMU European countries.

We further examine the cross-border M\&As within Europe by business function, namely, traditional banking (banking), investment banking (finance), and insurance in Table 5. The frequencies of banking and finance M\&As increased dramatically within EMU members from stage 2 to stage 3, but that of insurance M\&As declined. Nonetheless, the pattern is quite different among non-EMU countries. Among the different business functions of financial services, currency union probably has the most profound effect on investment banking because of its main association with capital market activities. On the contrary, insurance may receive the least benefit due to such an event. The findings here are consistent with the claim that EMU plays a role in the financial integration within Europe.

Figure 7 presents the relative importance of M\&As of different business functions by type of EMU membership. The percentage is scaled by each EMU type's capacity to have M\&A activities. It is obvious that the shares for investment banking (finance) M\&As increased from stage 2 to stage 3 for all categories with at least one EMU partner. Within the non-EMU group, both shares for banking and finance M\&As declined, however, that for insurance increased. These empirical observations are

Table 5

Cross-border within Europe M\&A deals by type of same business function.

The table reports the number of cross-border within Europe M\&A deals by type of same business function, i.e., commercial banking with commercial banking (Banking), investment banking with investment banking (Finance); and insurance and insurance (Insurance). The classification of business is based on a 2-digit SIC code. The 2-digit SIC codes for a commercial bank include 60, 61, and 67. That for an investment bank is 62 . Those for an insurance company are 63 and 64. EMU\&EMU indicates that both target and acquirer are countries with EMU memberships. TEMU\&ANEMU indicates that the target is from a country with EMU membership but the acquirer is from a nonEMU country, the opposite is true for AEMU\&TNEMU. NEMU\&NEMU indicates that both target and acquirer are non-EMU countries. Stage 1 is from 1 June 1988 to 31 May 1993. Stage 2 is from 1 June 1993 to 31 May 1998. Stage 3 is from 1 June 1998 to 31 May 2003.

\begin{tabular}{|c|c|c|c|c|}
\hline Stage & Banking & Finance & Insurance & All \\
\hline \multicolumn{5}{|c|}{ Panel A: EMU\&EMU } \\
\hline 1 & 116 & 7 & 67 & 190 \\
\hline 2 & 106 & 15 & 94 & 215 \\
\hline 3 & 175 & 25 & 77 & 277 \\
\hline \multicolumn{5}{|c|}{ Panel B: TEMU\&ANEMU } \\
\hline 1 & 27 & 12 & 44 & 83 \\
\hline 2 & 38 & 9 & 63 & 110 \\
\hline 3 & 53 & 24 & 56 & 133 \\
\hline \multicolumn{5}{|c|}{ Panel C: AEMU\&TNEMU } \\
\hline 1 & 40 & 7 & 48 & 95 \\
\hline 2 & 73 & 14 & 64 & 151 \\
\hline 3 & 79 & 38 & 83 & 200 \\
\hline \multicolumn{5}{|c|}{ Panel D: NEMU\&NEMU } \\
\hline 1 & 10 & 2 & 22 & 34 \\
\hline 2 & 12 & 11 & 24 & 47 \\
\hline 3 & 15 & 12 & 40 & 67 \\
\hline
\end{tabular}




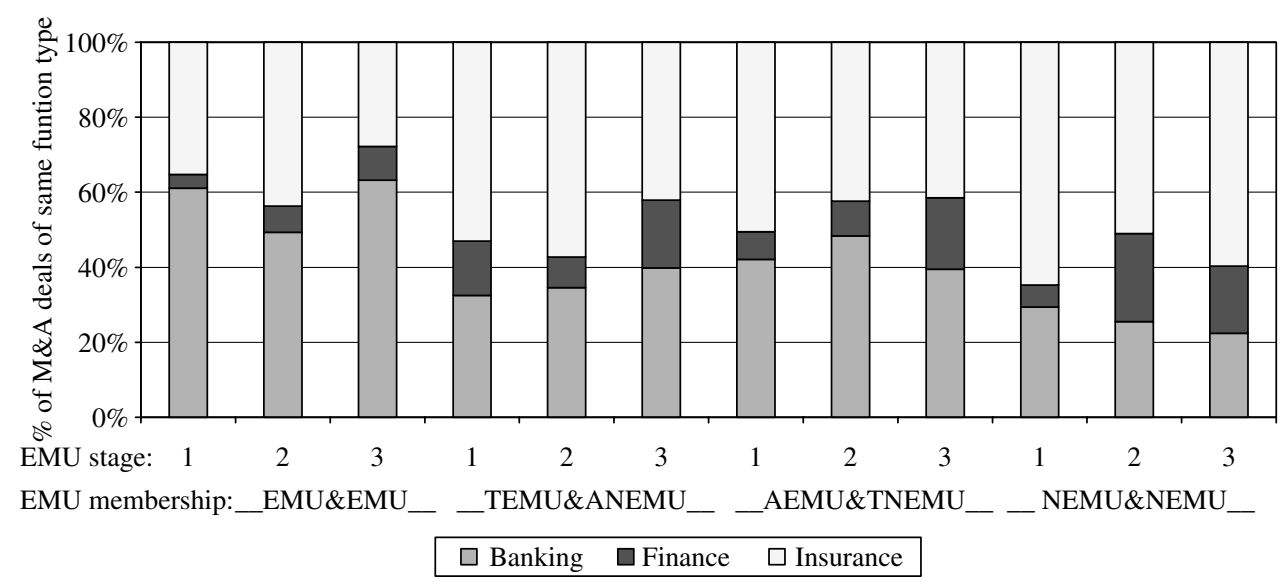

Fig. 7. M\&As of financial institutions by function type within Europe

The figure shows the percentage of cross-border within Europe M\&A deals by type of same business function, i.e., commercial banking with commercial banking (Banking), investment banking with investment banking (Finance); and insurance and insurance (Insurance). EMU\&EMU indicates that both target and acquirer are countries with EMU memberships. The classification of business is based on a 2-digit SIC code. The 2-digit SIC codes for a commercial bank include 60,61 , and 67 . That for an investment bank is 62 . Those for an insurance company are 63 and 64. TEMU\&ANEMU indicates that the target is a country with EMU membership but the acquirer is non-EMU country, the opposite is true for AEMU\&TNEMU. NEMU\&NEMU indicates that both target and acquirer are non-EMU countries. Stage 1 is from 1 June 1988 to 31 May 1993. Stage 2 is from 1 June 1993 to 31 May 1998. Stage 3 is from 1 June 1998 to 31 May 2003.

consistent with the argument that currency integration facilitates capital market integration, thus, more integration occurs among investment banking firms than insurance companies within the EMU group.

In summary, the evidence does point towards EMU enhancing regional integration. However, an investigation of the long-term impact of EMU and more detailed analyses of the different financial sectors remain to be done. As Berger et al. $(2001,2002)$ suggest, there are limits to the degree of future bank globalisation partly due to efficiency barriers to operating across borders. EMU may alleviate some of these barriers but not all.

\section{Conclusions}

This study uses the announcements of M\&As between financial institutions to examine the impact of EMU on financial integration in Europe. Because the surge in crossborder financial integration is evident in recent years as part of the globalisation of the financial services industry, we compare the extent of integration in relative terms. Among the three regions, Europe appears to have the highest level of regional integration traditionally. However, the trend of regional integration declined prior to the introduction of euro, but reversed surrounding EMU establishment. In relative terms, Europe increased in regional integration but decreased in terms of global integration following the EMU event. The opposite is true for Asia. There are no significant changes in North and South America. EMU appears to enhance regional integration in Europe, but does not facilitate entry by non-European institutions into Europe. 
The evidence within European indicates that EMU had little effect on non-EMU European integration, but reversed the trend of declining integration within the eurozone. In addition, cross-EMU integration (between EMU and non-EMU countries) following the introduction of the euro tends to have financial institutions from EMU states as acquirers rather than targets. The more active role of EMU institutions in the corporate control market suggests that EMU put these institutions in a stronger position in the market than those in non-EMU countries. Besides, the mergers initiated by EMU institutions also contribute to the pan-european integration, not just within the eurozone. Finally, the increased integration in the investment banking business within the euro area provides further support that EMU had an impact because currency integration should have a higher effect on capital market activities, thus, on investment banking business.

In sum, we show some evidence that is consistent with the claim that EMU plays a role in the financial integration of EMU members. Such an effect also seems to spill over to non-EMU European countries, although this is less pronounced compared to the impact on EMU members.

\section{References}

Beitel, P., Schiereck, D. and Wahrenburg, M., 'Explaining M\&A success in European banks', European Financial Management, Vol. 10, 2004, pp. 109-139.

Berger, A. N., Demesetz, R. and Strahan, P., 'The consolidation of the financial services industry: causes, consequences, and implications for the future', Journal of Banking and Finance, Vol. 23, 1999, pp. 135-194.

Berger, A. N., DeYoung, R., Genay, H. and Udell, G. F., 'Globalization of financial institutions: evidence from cross-border banking performance', Brookings-Wharton Papers on Financial Services, Vol. 3, 2000, pp. 23-158.

Berger, A., De Young, R. and Udell, G., 'Efficiency barriers to the consolidation of the European financial services industry', European Financial Management, Vol. 7, 2001, pp. $117-130$.

Berger, A. N., Dai, Q., Ongena, S. and Smith D. C., 'To what extent will the banking industry be globalized? A study of bank nationality and reach in 20 European nations', International Finance Discussion Paper No. 725 (Board of Governors of the Federal Reserve System, 2002).

Christie, E. and Marshall, A., 'The impact of the introduction of the euro on foreign exchange risk management in UK multinational companies', European Financial Management, Vol. 7, 2001, pp. 419-434.

Cybo-Ottone, A. and Murgia, M., 'Mergers and shareholder wealth in European banking', Journal of Banking and Finance, Vol. 24, 2000, pp. 831-859.

DeLong, G. L., 'Stockholder gains from focusing versus diversifying bank mergers', Journal of Financial Economics, Vol. 59, 2001, pp. 221-52.

DeYoung, R. and Nolle, D. E., 'Foreign-owned banks in the U.S.: Earning market share or buying it?' Journal of Money, Credit, and Banking, Vol. 28, 1996, 622-636.

di Giovanni, J., 'What drives capital flows? The case of cross-border M\&A activity and financial deepening', Journal of International Economics, forthcoming.

Eichengreen, B. and Park, Y. C., 'Why has there been less financial integration in Asia than in Europe?' Working Paper (University of California, Berkeley, 2003).

Evenett, S., 'The cross border mergers and acquisitions wave of the late 1990s', NBER Working Paper No. 9655 (National Bureau of Economic Research, 2003).

Goergen, M. and Renneboog, L., 'Shareholder wealth effects of European domestic and cross-border takeover bids', European Financial Management, Vol. 10, 2004, pp. 9-45.

(C) Blackwell Publishing Ltd, 2005 
Grosse, R., and Goldberg, L. G., 'Foreign bank activity in the United States: An analysis by country of origin', Journal of Banking and Finance, Vol. 15, 1991, 1093-1112.

Micco, A., Stein, E., and Ordonez, G., 'The currency union effect on trade: early evidence from EMU', Economic Policy, Vol. 37, 2003, pp. 315-356.

Mody, A. and Negishi, S., 'Cross-border mergers and acquisitions in East Asia: Trends and Implications', Finance and Development, Vol. 38, 2001, pp. 6-9.

Nolle, D. E., 'Foreign bank operations in the United States: Cause for concern?' in H. P. Gray and S. C. Richard (eds), International Finance in the New World Order (Oxford: Elsevier Sciences, 1995, pp. 269-377).

Rose, A. K., and Engel, C., 'Currency unions and international integration', Journal of Money, Credit, and Banking, Vol. 34, 2002, pp. 804-926. 